\title{
Karen Ever After: The Career \& Legal Consequences of being the Racist White Lady in an Internet Meme
}

\author{
Jennifer Rosen ${ }^{1}$, Heather Naughton\# and Heather Jones ${ }^{\#}$ \\ ${ }^{1}$ Wantagh High School, Wantagh, NY, USA \\ \#Advisor
}

ABSTRACT

With the coupled crises of the COVID-19 pandemic and racial protest movements in 2020, the "Karen" meme gained national attention as more incidents were posted online. These incidents have shown to be destructive to all parties involved as victims often experience negative health effects while "Karens" experience doxing. This study investigated the defaming career and legal consequences following the release of video content on social media in which a white woman dubbed as a "Karen" displays racist behaviors. Utilizing a directed qualitative content analysis, the sourcing of incident content came from a study by Been Verified that evaluated 150 incidents. A 2-part data-collection was implemented utilizing Advanced Google Search Engine and Chan McNamarah's research on racialized police communication. Incidents were subsequently processing using a selection criterion to be considered for consequence assessment. Out of 56 qualified incidents, $27 \%$ had discovered career consequences and $27 \%$ had discovered legal consequences. This research contributes to a largely undiscussed field in academia by providing an in-depth assessment on defaming Internet trends. It has implications for HR specialists and policymakers in making appropriate decisions to ensure accountability is taken in online matters. It also holds significance for Internet-users in understanding how one's digital footprint can be perceived online.

\section{Introduction}

Following the public release of the World Wide Web in 1993, the virtual creation and circulation of memes had had a profound impact on Internet users' visual and auditory language. The term "meme" was first coined by evolutionary biologist Richard Dawkins in his 1976 books The Selfish Gene. The term was initially defined as, "a noun that conveys the idea of a unit of cultural transmission, or a unit of imitation" (Dawkins, 1976, p. 192). Over the following decades, the term was reappropriated by the Internet to describe virtually distributed images and videos that use associated text to provide humorous commentary. After seeing the new use of his term, at the 2014 Saatchi \& Saatchi New Creators Showcase, Dawkins explained, "[T]he very idea of the meme, has itself mutated and evolved in a new direction. An Internet meme is a hijacking of the original idea. Instead of mutating by random chance, before spreading by a form of Darwinian selection, Internet memes are altered deliberately by human creativity" (Dawkins, 2013).

This study aims to understand this "new direction" through the qualitative analysis of the viral Internet trend, the "Karen" meme. This was done by assessing the prevalence of defaming career and legal consequences following the release of video content of "the racist white lady" displaying entitled, arrogant behaviors in a public setting. 56 qualified incidents determined by a selection criterion were analyzed for consequence assessment. Results prove to forward understanding of the Internet's effect on reputations, networking, digital practices, and behaviors. 


\section{Literature Review}

The rapid growth and international presence of social media has largely been forwarded by human's natural drive to communicate. From the 1844 development of Morse Code in which a series of electronic dots and dashes were tapped out by hand on telegraph machines, to the 1980-90s advancement of online communication services such as CompuServe, America Online, and Prodigy, to today's modern social media outlets housing over 5 billion mobile device users, the world has become much smaller in its ability to communicate data, stories, and opinions (Maryville University, 2021). In a society that has become vastly dependent on these social media outlets, meme culture has come to span over numerous platforms including Facebook, YouTube, Instagram, Tik Tok, Snapchat, Reddit, etc. According to the Department of Mass Communication and Journalism at Kristu Jayanti College, "Memes have become an integral part of the netizen [Internet user] vernacular. Trolls and memes are now the primary news source for youths. Memes are being shared from person to person and is now treated as a cultural unit" (Rasheed et al., 2020, p. 1985). Features on social media interfaces including feeds, profiles, comment sections, and share and like options allow easy accessibility to a global networking community. Although helpful in transferring information, it has had the powerful ability to alter users' perceptions of America's justice system in providing lawful judiciary action in social justice matters. According to Nicola A. Boothe-Perry, a Professor of Law at Florida University, "The explosive use of social media has expanded the context of the meaning of relationships, including relationships specifically between clients and attorneys and more broadly between the public and the justice system" (Boothe-Perry, 2014, p. 73). The unprofessional and unethical public usage of social media, "Taints the image of the entire legal community and fuels the perception that lawyer professionalism has declined precipitously in recent decades. The implications of this behavior for the American justice system are extremely serious in that the behavior contributes to decreased public confidence in legal and judicial institutions..." (National Center for State Courts, 1999, p. 1). In a society that is ridden with belligerent political discourse, social pressures, and financial difficulties, memes have come to gauge public opinion on numerous controversial social justice issues through its natural integration of visual rhetoric.

One of the most prevalent memes that documents this kind of controversy is the ever-growing "Karen" meme. According to the European Journal of Cultural Studies, a "Karen" can be defined as "a racist white woman who uses her privilege to demand her own way at the expense of others" (Negra and Leyda, 2020, p. 350). When searching "Karen slang definition" on Google, the first definition provided by Wikipedia defines "Karen" as, "a pejorative term for a white woman seeming to be entitled or demanding beyond the scope of what is normal" (Karen (slang), 2020). According to Know Your Meme, an online encyclopedia dedicated to researching the history of Internet culture, the "Karen" meme does not have an official origin. However, there are speculations that it could have derived from numerous pop-culture references. Many believe the meme's origins date back to the 2004 film Mean Girls from protagonist, Cady Heron's, first interaction with the popular group known as "The Plastics" (made up of Regina George, Gretchen Wieners, and Karen Smith) (Adam, 2019). In this scene, the girls invite Cady to their cafeteria table where Cady tells them about moving from her home-schooled life in Africa to public school in the United States. This provokes Karen Smith (characterized as the "dumb one" of the group) to ask, "So if you're from Africa why are you white?" (Mean Girls, 2004). With this allusion associating the name "Karen" with racial ignorance, the name began to be seen with a connotation of stupidity and insensitivity. Others believe the term originated from the 1990 gangster film Goodfellas (Adam, 2019). After Karen Hill, the wife of mob gangster Henry Hill, flushes $\$ 60,000$ worth of illegal drugs down the toilet to prevent the FBI from finding it during their raid, Henry goes into an angry rage as he repeatedly screams, "Why'd you do that Karen?!" (GoodFellas, 1990). This forwarded the stereotype of a "Karen" being short-sighted and senseless. The perpetuation of a stereotypical "Karen" having an unlikeable personality spawned the creation of the Reddit community "/r/FuckYouKaren" that was devoted to mocking this annoying "Karen" character through comedic scenarios. In 2018, a popular series of jokes spread when a male Reddit user referenced the name to complain about his ex-wife taking him into a child custody battle. Other jokes associated the name with women who demand to "speak to the manager" over minor inconveniences and who believe in the disproved idea that adverse symptoms to immunization cause autism spectrum disorders (Adam, 2019). 
What started as a light-hearted comedic ruse eventually prompted many to start filming real-life "Karens" who were seen to be aggressively displaying racist, entitled behavior. One of the earliest and most viral incidents came in 2018 when Jennifer Schulte, nicknamed "Barbeque Becky," called the police on a group of Black men barbequing in a public park. In the same year, the alliterative nicknames "Permit Patty" and "Cornerstore Caroline" were granted to women for having called 911 on African American children over minor and/or disproved inconveniences (Farzan, 2019).

The blatant display of racism that can be seen in these videos is very damaging for victims and "Karens" alike. For victims, experiencing any form of racial discrimination provides numerous pervasive impacts on development. According to Mental Health America, a non-profit organization that serves to educate about mental health issues, experiencing racial trauma can result in the rise of stress hormones which can lead to physical conditions like high blood pressure and heart disease, as well as mental health conditions like depression and anxiety (Racism and Mental Health, 2020). As to the "Karens," when their video is posted online, their face is often not blurred which can lead to doxing where hackers publish private, identifying information. This often results in many "Karens"” social media being spammed with hateful comments and death threats and ultimately, they can lose their job, respect in society, and be subject to legal consequences. This trend has come to be mutually destructive to all parties involved and demonstrates the regular experiences of racism that people of color live with in the United States.

The "Karen" trope has only escalated in 2020 with the growing stress of the coronavirus (COVID-19) pandemic and the rise of racial protest movements. According to Google Trends, the search term "Karen," gradually rose from a half popularity score of 50 at the beginning of May 2020, to a peak popularity score of 100 by August 2020.

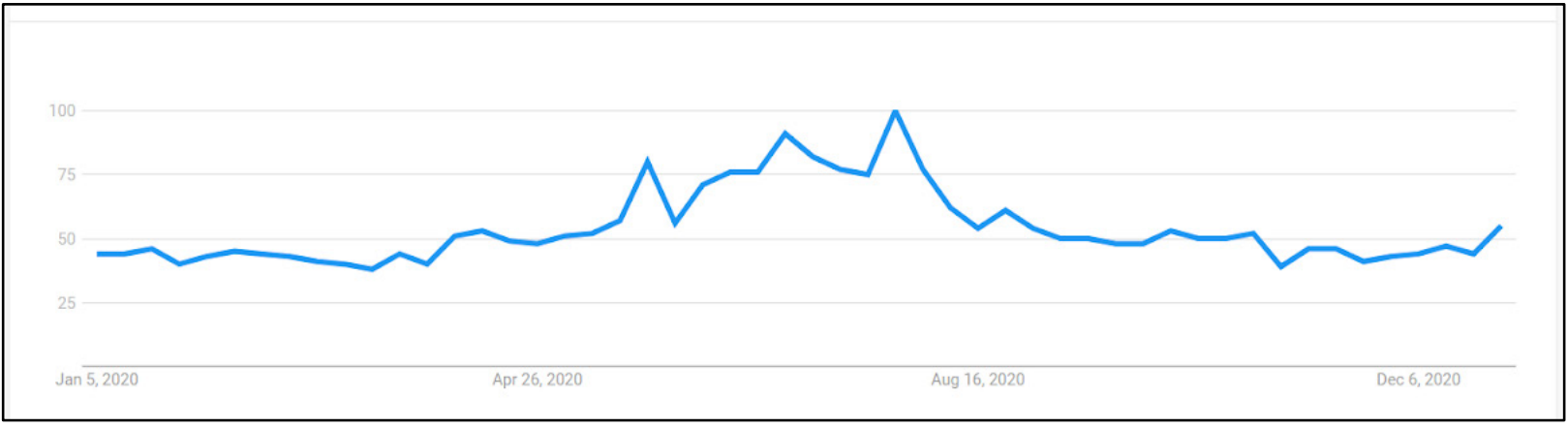

Figure 1. Data source: Google Trends (https://www.google.com/trends); Interest over time of the search term "Karen" from January 2020 to December 2020

This sudden rise in search popularity is likely correlated to the expansion of the term's meaning and presence in mainstream media. The nickname and hashtag "Anti-masker Karen" began to be used on the Internet to describe individuals who were recorded not following COVID-19 health guidelines by fighting with store employees over mask-wearing, spitting on customers, and dismissing social-distancing rules. The term was greatly popularized following an incident in May 2020 where white woman Amy Cooper called the cops on an African American birdwatcher who had asked her to leash her dog (Vera and Ly, 2020). With the incident occurring around the same date as the May 2020 murder of George Floyd, the story caught national attention and re-stimulated the popularity of the term across the Internet.

The meme has often sparked controversy with those who condemn it arguing that it is sexist, ageist, and racist against middle-aged white women. In an April 2020 Tweet by radical feminist writer Julie Bindel, she begs the question, "Does anyone else think the 'Karen' slur is woman hating and based on class prejudice?" (Bindel, 2020), consequently sparking a social media firestorm. In direct response to the question, Hadley Freeman, a columnist, and features writer for The Guardian wrote, "Yes - it's sexist, ageist and classist, in that order...Do I really need to spell out the sexism of a meme about a woman's name that took off from a man griping about his ex-wife and has become 
a way of telling women to shut up?" (Freeman, 2020). Others argue that this is a trend that has been seen before and that it is necessary to call out these behaviors, keeping in mind African American history. In response to Freedman's article, Washington Post Global Opinions editor Karen Attiah argued that men's names have also been used to depict problematic behavior, referencing the use of the derogatory epithet "Uncle Tom." She goes on to cite the trauma of white womanhood on the lives of African Americans throughout history and how even in recent years, white women calling the police unnecessarily for petty crimes has resulted in numerous stories of African Americans being arrested or assaulted. "Becky and Karen memes and jokes should be understood in this context, part of a long tradition to use humor to try to cope with the realities of white privilege and anti-blackness" (Attiah, 2020).

Although discussion and debate over the "Karen" trend has been seen across the media, current academia contains minimal investigation on the phenomenon. Limor Shifman, a memetics researcher from the Hebrew University of Jerusalem describes how memes, "Have been the subject of constant academic debate, derision, and even outright dismissal" (Shifman, 2013, p. 362). There has been little to no academic research implementing a qualitative content analysis to investigate the trend and the subsequent consequences "Karens" face. This study intends to do just that through the implementation of a directed qualitative content analysis, utilizing pre-existing studies as guidelines for consequence categories and sourcing of incident content. This study focused on race-related videos instead of antimask ones since according to Yeshiva University, racial injustice was one of the biggest social justice issues coming out of 2020. "Racism has a long history in the United States, and its impact can be found in every facet of education, business, media and day-to-day life. After the killing of George Floyd in Minnesota and several other high-profile police shootings, Black Lives Matter protests took place across the country and have continued as activists demand substantial change" (9 Biggest Social Justice Issues of 2020, 2020).

To determine the basis of consequences evaluated in this study, the work of Nicole Muscanell, a graduate student at the University of Alabama, was drawn upon. In offering an in-depth evaluation on inappropriate online selfpresentation, she was able to examine whether failures in self-regulation can explain why some individuals share inappropriate information through social media. Muscanell describes how the "Negative consequences for posting questionable material on sites such as Facebook include being fired from one's job, being expelled from school, and criminal prosecution" (Muscanell, 2013, p.1). This was used as the basis of consequences evaluated in this study since a "Karen's" online image is forever tarnished by their recorded actions. However, since a "Karen" is stereotypically not of schooling age, expulsion was eliminated as a consequence category leading to the development of the research question: How often do "Karens" face career and legal consequences following the release of video content showing that individual display racist behavior in a public setting?

\section{Methods}

\section{Qualitative Content Analysis}

This study followed the model of a qualitative content analysis. This method allowed for the gathering of large amounts of data to be subsequently transformed into a highly organized structure through categorization and coding. With the resurgence of the "Karen" meme in 2020, social media users have come to share this kind of content through specified hashtags across numerous platforms. It has resulted in the meme being very widespread and difficult to categorize. This method provided direction in gathering relevant media coverages to find the defaming career and legal consequences of being dubbed a "Karen" on the Internet.

\section{The Gathering of Incident Content through the Directed Approach}

According to Hsiu-Fang Hsieh and Sarah Shannon from Fooyin University and the University of Washington, Seattle, qualitative content analysis can be conducted under three approaches: conventional, directed, or summative (Hsieh 
and Shannon, 2005). This research question fit best with the methods of a directed approach since this study aims to provide conclusive numerical findings on each category of consequences using pre-existing studies as guidelines for consequence categories and the sourcing of incident content.

Consequence categories were derived from the aforementioned work of Muscanell while the foundational source for the gathering of incident content came from a 2020 data analysis study by Been Verified (BV), a background check company, that evaluated 150 incidents between January 2018 to July 2020 (Been Verified Team, 2020). After obtaining the summary sheet, a number was assigned based on the chronological dates of incidents (abbreviated as Inc. \# in all provided figures).

Since the summary sheet only provided information as to the date, establishment, city, and state of each incident, it was necessary to use the provided information to find media coverage providing extractable data related to what happened in each incident and who was involved. A 2019 study on racialized police communication by Cornell Law School J.D. Candidate Chan Tov McNamarah provided this relevant information for the 97 incidents in 2018 included in the BV study (Mcnamarah, 2019). However, since there was no previous academic study that provided the other 53 incidents from 2019-2020, the dates and locations in the summary sheet were used as search terms to find each incident through Advanced Google Search Engine (AGSE). This method of search was employed since according to the University of Arizona, it helps provide more control over finding relevant and successful search results. It allows for the finding of pages that contain or eliminate specific words and phrases by using advanced shortcuts and thereby helps in taking millions of results and limiting them to thousands (University Staff, 2020). By using AGSE and its associated shortcuts provided by Modesto Junior College as shown below (Google for Researchers: Google Advanced Search, 2021), media coverage for each incident was discovered and assessed. With a combination of these shortcuts in the search bar, results were then further limited by publication date through the Tools feature from the incident date to 2-6 months later to ensure results were consistent with the timeline of incidents.

Table 1: Advanced Search Shortcuts used to find incidents: Provided by Modesto Junior College (Google for Researchers: Google Advanced Search, 2021

\begin{tabular}{|c|c|c|c|}
\hline Shortcut & Example & Purpose & Was it used for this Study? How/Why \\
\hline $\begin{array}{l}\text { Quotation } \\
\text { Marks }\end{array}$ & $\begin{array}{l}\text { "Employee partici- } \\
\text { pation" }\end{array}$ & $\begin{array}{l}\text { Provides results that con- } \\
\text { tain that exact phrase }\end{array}$ & $\begin{array}{l}\text { Yes: helped limit results from millions to thou- } \\
\text { sands based on specificity of word choice } \\
\text { "[city] karen" } \\
\text { "racist karens [year]" } \\
\text { "karen [city] [date]" }\end{array}$ \\
\hline Hyphen & salsa-dance & $\begin{array}{l}\text { Gives results for only } \\
\text { words prior and excludes } \\
\text { anything to do with words } \\
\text { following hyphen }\end{array}$ & $\begin{array}{l}\text { No: no specific sequence of words came up } \\
\text { enough to deem it necessary to be limited }\end{array}$ \\
\hline Domain:_ & domain: .gov & $\begin{array}{l}\text { Specifies results to spe- } \\
\text { cific domains }\end{array}$ & $\begin{array}{l}\text { No: the difference in the domain ending would } \\
\text { not have helped in finding relevant results }\end{array}$ \\
\hline Site: _ & $\begin{array}{l}\text { site: youtube.com } \\
\text { site: pewre- } \\
\text { search.org }\end{array}$ & $\begin{array}{l}\text { Returns results from only } \\
\text { the specified pertained } \\
\text { website }\end{array}$ & Yes: helped the find videos for each incident \\
\hline Filetype: _ & filetype: pdf & $\begin{array}{l}\text { Returns results with only } \\
\text { specified file type struc- } \\
\text { ture }\end{array}$ & $\begin{array}{l}\text { No: irrelevant to study. The limitation of file } \\
\text { type would have only hindered results }\end{array}$ \\
\hline Database & $\begin{array}{l}\text { California sex trade } \\
\text { database }\end{array}$ & $\begin{array}{l}\text { Helps find searchable da- } \\
\text { tabases }\end{array}$ & $\begin{array}{l}\text { No: irrelevant to study. The limitation of the } \\
\text { database would have only hindered results }\end{array}$ \\
\hline
\end{tabular}




\begin{tabular}{|l|l|l|l|}
\hline & & & $\begin{array}{l}\text { since it likely would associate "Karen" with the } \\
\text { author's name being Karen }\end{array}$ \\
\hline Related: _ & $\begin{array}{l}\text { related: } \\
\text { www.imdb.com/ }\end{array}$ & $\begin{array}{l}\text { Putting "related" in front } \\
\text { of a web address you } \\
\text { know already to find re- } \\
\text { lated sites }\end{array}$ & $\begin{array}{l}\text { No: irrelevant to study. Study does not focus on } \\
\text { the source but rather on the content presented }\end{array}$ \\
\hline
\end{tabular}

The extractable data that was gathered included video links, social media links, news links, descriptions of incidents, and the names/nicknames of "Karens" (which will not be stated to preserve the rights to confidentiality).

\section{Incident Selection Criterion}

After obtaining all relevant coverage of incidents, incidents were processed through a selection criterion to be considered for the next data collection involved in consequence assessment. Incidents were included in which (1) the incident could be identified based upon the availability of extractable data, (2) a cell phone video was present that allowed viewers to see the altercation occur first-hand, and (3) the gender of the "Karen" was female (as this study followed the provided "Karen" definition). Incidents were excluded in which (1) an incident was unidentified because of there being no extractable data, (2) the video was taken down and could not be accessed through another platform or there was only a caption or picture giving context to the incident, and (3) if the gender of the "Karen" was male or could not be identified. Based on this, 56 incidents qualified and were taken into the next data collection for consequence assessment.

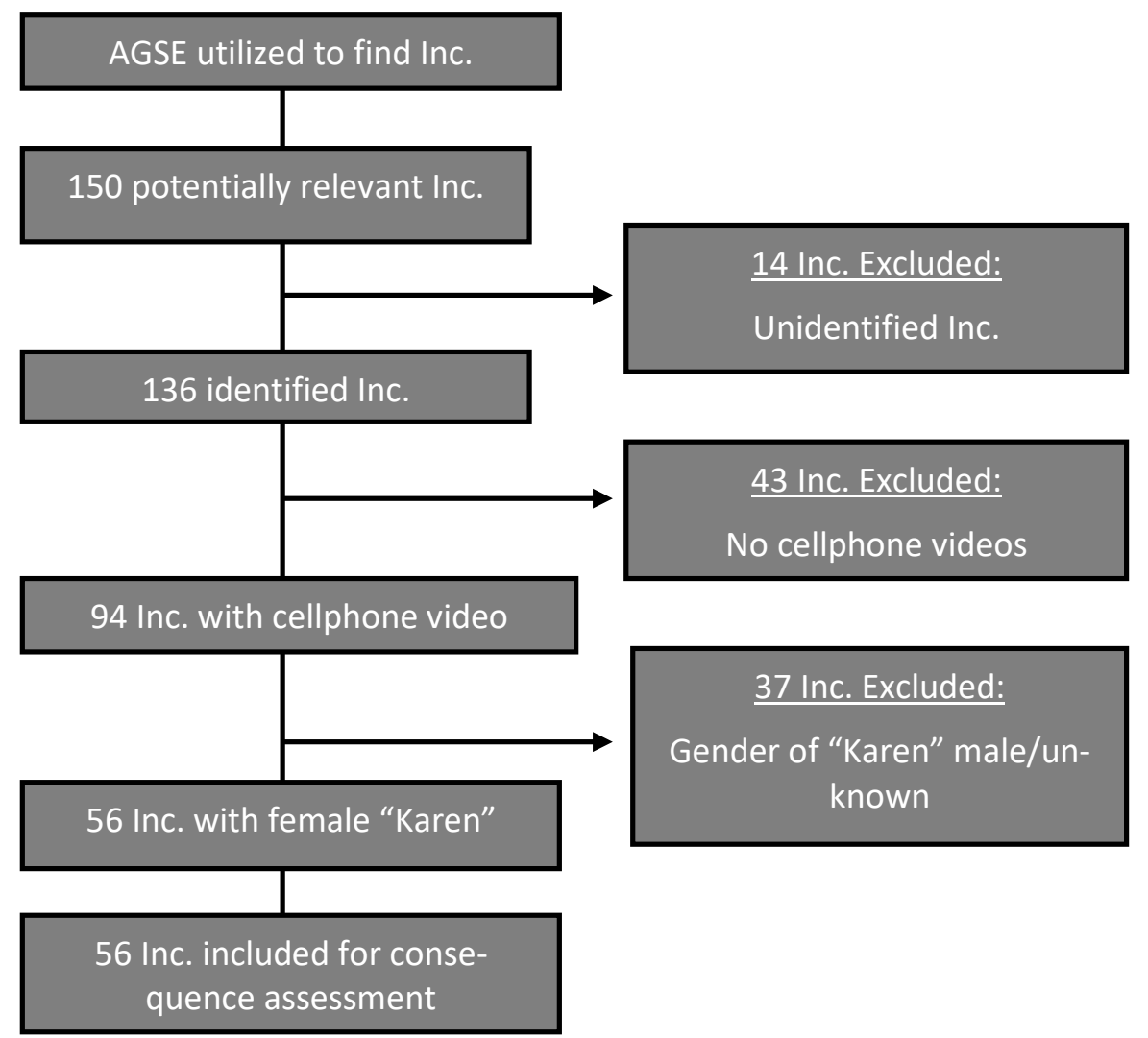

Figure 2. Flow chart of the selection criterion providing if incidents were considered for consequence assessment 


\section{Consequence Assessment through the Directed Approach}

The 56 qualified incidents were subsequently evaluated based on a "Karen's" career and legal consequences following the release of their video. Qualifications that made up the career consequence category included a "Karen" being fired/resigning from their place of employment and/or an associated company, university, or business publicly distancing themselves from the "Karen." Qualifications that made up the legal consequence category included suing, charges being pressed, and/or new bills being enacted directly following the altercation. To find the associated career and legal consequences for each incident, AGSE was once again utilized. The real names/nicknames of each "Karen" and related career and legal search terms were surrounded with quotes to attempt to get results that had those related consequences. For example, when trying to find career consequences, associated real names of "Karens" were searched with words such as "fired," "terminated," or "let go," in quotes. In trying to find legal consequences, words such as "lawsuit," "charged," or "prosecuted" were searched with the associated real names of "Karens." Articles that came up as results were then analyzed to find if the "Karen" was described to have experienced any career or legal consequences following the release of their video.

\section{The Coding of Data}

After data collection, each incident that had shown to have consequences occur was quantified through counts and percentages. A total sum of incidents that showed career and legal consequences to have occurred was added up to have a numerical value in each category. To find out in percentage form how many incidents led to career consequences, the number of incidents with career consequences was divided by the total number of qualified incidents and multiplied by 100 as shown below. The same was done with legal consequences. Through this process, an overall conclusion to the dataset could be drawn.

$$
\frac{(\# \text { with Career Conseq. })}{56(\text { Total Inc. })} \times 100
$$

\section{Results}

Out of the 56 qualified incidents, only a minority had discovered consequences. Approximately $27 \%$ of included incidents had discovered career consequences with $60 \%$ of those incidents resulting in a "Karen" being fired from their job, and approximately $13.3 \%$ resulting in a "Karen" resigning from their position.

Table 2: 15 incidents with discovered career consequences

\begin{tabular}{|l|l|}
\hline Inc. \# & Career Consequences \\
\hline 7 & Fired from job \\
\hline 12 & University released a public statement distancing themselves from the name after rumors of association \\
\hline 33 & $\begin{array}{l}\text { - Resigned as CEO } \\
\text { - Dispensaries pulled products off shelves }\end{array}$ \\
\hline 42 & Fired from job \\
\hline 49 & Fired from job \\
\hline 50 & Placed on leave \\
\hline 73 & Fired from job \\
\hline 78 & Fired from job \\
\hline 87 & Suspended from teaching at university \\
\hline 106 & Fired from job \\
\hline
\end{tabular}




\begin{tabular}{|l|l|}
\hline 112 & Fired from job \\
\hline 129 & Fired from job \\
\hline 131 & Urged for disbarment, unknown if went through \\
\hline 136 & $\begin{array}{l}\text { - Resigned as CEO } \\
\text { - Distribution companies cut ties }\end{array}$ \\
\hline 145 & Fired from job \\
\hline
\end{tabular}

Approximately $27 \%$ of qualified incidents had discovered legal consequences with approximately $60 \%$ of those incidents resulting in charges being pressed against the "Karens," approximately 13.3\% resulting in separate bills being passed by governing bodies, and approximately $13.3 \%$ resulting in a "Karen" wanting to press charges against the victims (extraneously, the data also showed that approximately $60.7 \%$ of the qualified incidents had the real name of the "Karen" identified).

Table 3: 15 incidents with discovered legal consequences

\begin{tabular}{|l|l|}
\hline Inc. \# & Legal Consequences \\
\hline 12 & $\begin{array}{l}\text { Lawmakers introduce a bill regarding an individual Class C misdemeanor if someone calls law enforce- } \\
\text { ment to arrive for a reason other than criminal activity. }\end{array}$ \\
\hline 14 & $\begin{array}{l}\text { - Filed a request to see police footage to clear name } \\
- \text { Set up a GoFundMe seeking legal funds to hire an attorney }\end{array}$ \\
\hline 42 & $\begin{array}{l}\text {-Charged with one count of third-degree assault and two counts of assaulting a law enforcement officer. } \\
\text {-Plead guilty to assault and battery } \\
\text {-Ordered to pay } \$ 1,000 \text { fine. }\end{array}$ \\
\hline 74 & "Karen" wanted to press charges against mother who allegedly made threats against her life \\
\hline 78 & Arrested and charged with 4 criminal summons \\
\hline 100 & $\begin{array}{l}\text { "Karens" made false claims which caused victim to be falsely arrested } \\
- \text { Victim suing women and asking for } \$ 300 k \text { in damages. }\end{array}$ \\
\hline 106 & Charged with a single misdemeanor of threatening exhibition of a weapon \\
\hline 129 & Charged with filing a false police report \\
\hline 131 & Arrested and charged with disorderly conduct (hate crime and a felony) \\
\hline 133 & $\begin{array}{l}\text { - Charged with criminal battery in a separate racist incident } \\
- \text { Insufficient evidence to support filing criminal charges against tirades in this pertained incident }\end{array}$ \\
\hline 136 & Inspired CAREN Act \\
\hline 138 & Charged with simple assault, disorderly conducts, and second-degree trespassing \\
\hline 141 & "Karen" filed report after fight \\
\hline 142 & Charged with unlawful use of weapon \\
\hline 145 & Arrested and charged with one count of assault \\
\hline
\end{tabular}

\section{Discussion}

\section{Career Consequences: Significance of Results}

These career consequence results prove to be intriguing as the $13.3 \%$ of incidents in which a "Karen" resigned from their position poses that these individuals voluntarily left their positions upon "free-will." Although the decisions 
leading up to their resignation is unknown, it is possible that these individuals were pressured by co-workers, were worried for their safety after receiving online hate, and/or wanted to protect the company's reputation and profitability.

The finding that over half of the career consequences saw that a "Karen" was fired from their job was not surprising. Interestingly, all these incidents never occurred within an office environment but rather, on the "Karens"” time away from work. It is unknown whether these companies officially terminated, the "Karen" due to public pressure, but if that were true, it demonstrates the power of herd mentality on social media and how even after working hours, workers are still being judged on their performance. This is especially valid in an age where iPhones allow for everything to be recorded at a moment's notice. It poses an interesting question; if a "Karen" incident occurred but was unrecorded or not posted to social media, would that individual still have been fired? Hypothetically, if they were not, then a "Karen" being fired from their place of employment would prove not to come as a result of their actions, but rather upon the publicity of the individual's bad behavior acting as a liability to the company's reputation. Therefore, it is arguable that perhaps it is not an individual's actions that are most important in understanding negative selfonline presentation, but rather the level of visibility in which their actions can be seen.

Muscanell had intriguingly opened her dissertation by quoting Erin Bury, a Sprouter community manager who stated, "Don't say anything online that you wouldn't want plastered on a billboard with your face on it" (Muscanell, 2013, p.1). Despite this being a true consideration in understanding the spread of Internet users' own digital footprints, this message fails in illustrating the impact of how others' posts about another individual can affect that individual's reputation. In all 15 of these incidents, videos were uploaded by the victim or bystander instead of the "Karen" themselves, technically meaning that the "Karen" did not speak with the intention of having their actions spread online. This readily demonstrates that an individual's digital footprint is not just something one must consider upon one's own digitized actions, but also by the intentions and actions of others.

\section{Legal Consequences: Significance of Results}

These legal consequence results also prove to be intriguing as an overwhelming majority of incidents having legal consequences showed charges being pressed on the "Karens" on a variety of accounts including assault, battery, threat, filing a false police report, and disorderly conduct. It actively demonstrates that these victims wish to seek out justice and compensation for the racial abuse they experienced.

When victims and bystanders post these videos, they are not only holding the "Karens" accountable, but they are also serving as leaders in demanding that the behavior they experienced should not be acceptable. However, many question the meme's intentions in providing accountability and justice when the name "Karen" is often used to generalize these women. According to David Dennis, a journalist, and professor at Morehouse College, "These nicknames and memes are only shielding white women from real consequences they should get for putting Black lives in danger ... Giving them nicknames is providing aliases that cover the names of real women with real racist motivations to commit real harm to real Black people" (Dennis, 2019).

Dennis holds a slight difference in the views expressed by aforementioned Washington Post Global Opinions writer Karen Attiah. Attiah's piece strongly affirmed the use of the name "Karen" to describe these individuals and wrote intending to alter its perception as a slur (Attiah, 2020), whereas Dennis argues for the complete elimination of its use. Although different in purpose, both pieces reference the trauma of African American history as a means of establishing legal justice to demand accountability. With only approximately $60.7 \%$ of "Karens" having their real names discovered, these results demonstrate that there is still hesitation in addressing these individuals in the media (possible reasons explored in the next section).

The finding in which $13.3 \%$ of incidents resulted in the passage of legislation regarding the usage of 911 poses that accountability is being taken into consideration to prevent the spread of these incidents. However, Dennis provides skepticism in legislation's ability to achieve what it says it will. "Such a law would be asking police to side with an innocent Black person over a white person, which doesn't usually garner great outcomes for us [African Americans]" (Dennis, 2019). This sense of mistrust has only heightened with the rise of "Karen" incidents and posits 
that more research must be undertaken to understand the spread, cultural, and expressive impact of this phenomenon on the lives of racial minority groups in America.

\section{Potential Reasons for the Limited Coverage of Data}

It had initially been predicted that this methodology would allow for quantitative findings to be obtained in each category of consequences. With the majority of qualified incidents having unknown consequences, there was an attempt to understand the legal confines of journalism that could explain this lack of available coverage.

During a consultation session with Steven A. Glazer, Esq., an Administrative Law Judge at the Federal Energy Regulatory Commission on why he thinks these results present themselves, he initially credited this lack of media coverage to reporters' fear of being sued for character defamation. Judge Glazer defines defamation as, "the underprivileged publication of a false oral or written statement that harms the reputation of another person." Judge Glazer goes on to describe how, "Despite the chances of a "Karen" suing for defamation, defamation suits are difficult for them to bring in court. There is almost always a cell phone video, so the truth is easy to establish. The recorder has truth as an absolute defence and even if defamation somehow can be provided, juries often award damages of only one dollar in these cases, because they lose the respect of the plaintiff ["Karen"] in making such a big deal of insult."

Additionally, Judge Glazer points out that there is another argument that a "Karen" can make in court, the invasion of privacy. Judge Glazer cited an 1890 Harvard Law review by Boston lawyers Samuel Warren and Louis Brandeis that provided what is largely regarded as the first publication in the United States to advocate a right to privacy. The review provides that, "Gossip is no longer the resource of the idle and of the vicious, but has become a trade, which is pursued with industry as well as effrontery ... Even gossip apparently harmless, when widely and persistently circulated, is potent for evil. It both belittles and perverts. It belittles by inverting the relative importance of things, thus dwarfing the thoughts and aspirations of a people" (Warren \& Brandeis, 1890, p. 196).

As a news media source tasked with the responsibility of providing truth through informing and stimulating thought and debate, being sued for either of these claims diminishes the credibility of the source. Judge Glazer described how, "Most large newspapers have law departments made up of in-house corporate counsel. Lawyers who are hired by people accused of being 'Karens' in the newspaper can send the newspaper a letter that tells it to cease and desist publishing the article and/or follow-ups to the article, and/or to retract the article and/or issue an apology, and/or face a lawsuit. The in-house lawyers take these letters very seriously. If they get too many of these letters, the newspaper's reputation for truthfulness is maligned which is the main reason for its business."

Reporters' fear of being sued serves as legitimate potential reasons as to why there was a lack of media coverage of consequences that hindered the results presented in this research.

\section{Conclusion}

To try and curb the mass number of undiscovered consequences, there needs to be a different method of data collection that provides less ambiguity in results. If a future researcher has access to a private legal database, this would be very helpful in finding results as it would provide an up-to-date legal status on each incident. Similarly with career consequences, having access to an employment database would help provide a definitive evaluation for a "Karens" presiding employment status. The use of databases would not rely on the available coverage of media that can often be biased in framing stories and consequences and would provide a better means of gauging content. Future research replicating the data collections would also assist in ensuring validity and an up-to-date assessment of any updates that arise in specific incidents.

There are a multitude of directions that can be taken with this research. Between attempting to assess the psychological, cultural, historical, or sociological branches of research, there is a vast gap to be filled within this trend. It was found that there were questions that were left unanswered within the presentation of the provided dataset that 
can be investigated in more depth for future study. Such questions include: What are the series of events leading up to a recorded altercation? How are relationships impacted after an individual has gone viral for being a "Karen?" Do male "Karen" videos and female "Karen" videos receive the same kind of viral recognition? How do race-related "Karen" videos compare to anti-mask-related "Karen" videos? What makes a high-profile "Karen" incident? Is there a correlation between political/economic/social climate and the number of "Karen" incidents? These questions are worth exploring to better understand the "Karen" meme's fullest potential.

\section{Limitations}

Due to the nature of the sourcing of content being dependent upon coverage in the news media and Advanced Google Search Engine, the consistent finding and processing of data was difficult and must be improved upon in future research.

Since the researchers of the provided BV data analysis study could not send their full data collection sheet, this resulted in having to find the sourcing of incident content independently. The content collected may not have been the same as those collected by BV, yielding an inconsistent understanding of what happened in each incident. Similarly, the selection criterion limited much of the analyzed content as it resulted in approximately $62.7 \%$ of incidents being excluded. This means that for future studies, there either needs to be less strict criteria for the inclusion of incidents or different sourcing of content.

The methodology modelled upon for this research was initially viewed with the expectation that utilizing AGSE would result in the presentation of numerous, relevant news articles that would thoroughly describe consequences, similar to the high-profile incidents of "Barbeque Becky," "Permit Patty," "Cornerstore Caroline," and "Central Park Karen." However, in many lower-profile incidents, coverage was limited and for stories that were available from different sources, they were often word-for-word the same where they described the incident without follow-up. Also, with lower-profile incidents, if a video owner decided to private and/or remove the original video from their social media account, it was very difficult to find it reposted on another account, forcing it to be excluded from the dataset.

Despite the use of AGSE, available and relevant data was inconsistent. In many instances, relevant information was not always found when entering associated career and legal search terms in quotes. Putting a word in quotes in AGSE could mean that that word may show up anywhere on the page, and not always in the content of the paper. If a news article has ads or recommended stories with that word, it can still show up as a result despite its irrelevance, making consequences even more difficult to trace back. Further, in many incidents, consequences were described using probable language such as "hope," "should," "would," and "could" instead of definitively providing if any of those consequences were followed through. It was also seen that while attempting to find career consequences, many "Karens"” places of employment were vague in the public release of the individual's employment status. It made it difficult to gauge conclusive findings.

Since this is a trend that has shown to be mutually destructive to all parties involved, there needs to be more research done to understand the meme's virtual and cultural spread concerning common patterns seen in incidents. Although a content analysis was an adequate form of assessing what media has already provided on the subject, it more so emphasizes the gathering and coding of existing data. For future studies, it is strongly advised to attempt to provide a new anecdotal-based data set through a case study. In gathering a group of eight to twelve "Karens" to participate in a survey or interview to evaluate the events leading up to documented incidents and subsequent consequences, there would be more personal details and evidence that may not have been provided in the media. Although the lack of available coverage did hinder the results presented in this study, this research helps provide a first step to a larger field at hand that is not actively analysed. It concretely provides research to those who wish to investigate the discussion of racial issues in America and how an individual's digital footprint can be perceived online. 


\section{Acknowledgments}

I would like to thank Heather Naughton and Heather Jones for helping me with this research.

\section{References}

9 Biggest Social Justice Issues of 2020. (2020, March 16). https://online.yu.edu/wurzweiler/blog/2020-biggestsocial-justice-issues.

Adam. (2019). Karen. Know Your Meme. https://knowyourmeme.com/memes/karen.

Attiah, K. (2020, April 28). Opinion | The 'Karen' memes and jokes aren't sexist or racist. Let a Karen explain. The Washington Post. https://www.washingtonpost.com/opinions/2020/04/28/karen-memes-jokes-arent-sexist-or-racistlet-karen-explain/.

Been Verified Team. (2020, August 5). Where the 'Karens' Are: California, New York Top States for Viral Incidents. Been Verified. https://www.beenverified.com/data-analysis/karen-memes-viral-incidents-study/.

Bindel, J. (2020, April 5). Does anyone else think the 'Karen' slur is woman hating and based on class prejudice? Twitter. https://twitter.com/bindelj/status/1246800996841467908?s=20.

Boothe-Perry, N. A. (2014). Friends of Justice: Does Social Media Impact the Public Perception of the Justice System? . Pace Law Review, 35(1), 72-115. https://doi.org/https://digitalcommons.pace.edu/plr/vol35/iss1/3

Dawkins, R. (1976). Memes: the new replicators. In The Selfish Gene (pp. 1-360). essay, Oxford University Press.

Dennis , D. (2019, March 1). Please Stop Giving Racist White Women Adorable Nicknames. NewsOne. https://newsone.com/3831926/racist-white-women-nicknames/.

Farzan, A. N. (2019, March 29). BBQ Becky, Permit Patty and Cornerstore Caroline: Too 'cutesy' for those white women calling police on black people? The Washington Post. https://www.washingtonpost.com/news/morningmix/wp/2018/10/19/bbq-becky-permit-patty-and-cornerstore-caroline-too-cutesy-for-those-white-women-callingcops-on-blacks/.

Freeman, H. (2020, April 13). The 'Karen' meme is everywhere - and it has become mired in sexism. The Guardian. https://www.theguardian.com/fashion/2020/apr/13/the-karen-meme-is-everywhere-and-it-has-become-mired-insexism.

Hsieh, H.-F., \& Shannon, S. E. (2005). Three Approaches to Qualitative Content Analysis. Qualitative Health Research, 15(9), 1277-1288. https://doi.org/10.1177/1049732305276687

Maryville University. (2021). The Evolution of Social Media: How Did It Begin, and Where Could It Go Next? [web log]. https://online.maryville.edu/blog/evolution-social-media/.

McNamarah, C. T. (2019). White Caller Crime: Racialized Police Communication \& Existing While Black. Michigan Journal of Race and Law, 24, 335-415. https://doi.org/10.2139/ssrn.3312512 
Modesto Junior College. (2021). Google for Researchers: Google Advanced Search. Research Guides. https://libguides.mjc.edu/c.php?g=255744\&p=1706104.

Muscanell, N. L. (2013). Fired for What You Post Online? A Self-Regulatory Perspective on Inappropriate Online Self-Presentation (dissertation). Department of Psychology in the Graduate School of The University of Alabama, Tuscalo, AL. https://ir.ua.edu/bitstream/handle/123456789/1811/file 1.pdf?sequence=1\&isAllowed=y

National Center for State Courts. (1999). In A National Action Plan on Lawyer Conduct and Professionalism: A Report of the Working Group on Lawyer Conduct and Professionalism (pp. 1-95). The Working Group on Lawyer Conduct and Professionalism. https://ccj.ncsc.org/ data/assets/pdf file/0024/23388/national-action-plan-full.pdf

Negra, D., \& Leyda, J. (2020). Querying 'Karen': The rise of the angry white woman. European Journal of Cultural Studies, 24(1), 350-357. https://doi.org/10.1177/1367549420947777

Paramount Pictures. (2004). Mean Girls. United States.

Racism and Mental Health. Mental Health America. (2020). https://www.mhanational.org/racism-and-mentalhealth.

Rasheed, A., Maria, C., \& Michael, A. (2020). Social Media and Meme Culture: A study on the impact of Internet Memes in reference with 'Kudathai Murder Case'. Mukt Shabd Journal, 9(6), 1985-2006.

https://doi.org/09.0014.MSJ.2020.V9I6.0086781.104699

Saatchi \& Saatchi New Creators Showcase. (2013). Just for Hits - Richard Dawkins. YouTube. https://www.youtube.com/watch?v=GFn-ixX9edg\&t=272s.

Shifman, L. (2013). Memes in a Digital World: Reconciling with a Conceptual Troublemaker. Journal of Computer-Mediated Communication, 18(3), 362-377. https://doi.org/10.1111/jcc4.12013

University Staff. (2020, June 3). Search Tips: Google Scholar \& Advanced Google Search: UAGC: University of Arizona Global Campus. The University of Arizona Global Campus. https://www.uagc.edu/blog/search-tips-forgoogle-scholar-and-advanced-google-search.

Vera, A., \& Ly, L. (2020, May 26). White woman who called police on a black man bird-watching in Central Park has been fired. CNN. https://www.cnn.com/2020/05/26/us/central-park-video-dog-video-african-americantrnd/index.html.

Warner Brothers. (1990). Goodfellas. United States.

Warren, S. D., \& Brandeis, L. D. (1890). The Right to Privacy. Harvard Law Review, 4(5), $193-220$. https://doi.org/10.2307/1321160

Wikimedia Foundation. (2020). Karen (slang). Wikipedia. https://en.wikipedia.org/wiki/Karen_(slang). 